\title{
El reto de Bolonia: la evaluación de las competencias
}

\author{
Albert Oriol Bosch
}

Bolonia impone a las universidades del Espacio Europeo de Educación Superior (EEES) la educación orientada a resultados (outcome oriented education), aclarando que los resultados a los que se aspira conseguir deben expresarse en forma de competencias y exigiendo, además, que éstas sean mesurables, lo que supone, sin ningún tipo de dudas, que deben ser evaluadas. Las universidades en Europa deberán evaluar las competencias de sus graduados y ser a su vez evaluadas por los resultados que obtengan en su desempeño.

La evaluación de las competencias constituye un gran reto para las universidades por diversos motivos. En primer lugar, por la falta de experiencia institucional en dicho menester, por la complejidad que ello comporta y, finalmente, por la falta de recursos disponibles para llevar a cabo dicha tarea.

Las universidades, y las facultades de medicina en particular, tienen una estructura organizativa departamental que les dificulta la migración desde una enseñanza fragmentada en asignaturas para orientarla hacia la obtención de capacidades para el desempeño. Además, las facultades no se han dotado todavía de unidades educativas de apoyo interdepartamental con experiencia en los procesos evaluativos. Tradicionalmente no existen evaluaciones externas y la función evaluadora la llevan a cabo los mismos expertos en contenidos responsables de impartir la enseñanza de las asignaturas.

En segundo lugar, hay que tener en cuenta que las competencias son constructos complejos

\section{Bologna's challenge: assessment of the competencies}

The Bologna process demands the European Universities outcomes oriented education. The educational outcomes should be defined as measurable competencies, meaning that they have to be assessed. The European Universities are then supposed to evaluate the degree of competencies their graduates have achieved at graduation and they will in turn be assessed by the success of their graduates.

The assessment of the competencies of the graduating students poses a big challenge to the European Universities. First of all, because most of them lack institutional experience in doing it, then, because this is a complex affair, and finally because they lack resources to carry this sophisticated task.

Universities and Medical Schools particularly are organized with a departmental structure that impedes their migration from fragmented curriculum in subject matters towards educational programs directed to provide the students capacities of performance. Most of the Medical Schools in Europe have not equipped themselves with interdepartmental educational units with enough expertise in assessment processes. In most countries external evaluations are not in place and students' assessment is in the hands of the content experts responsible of the teaching of the different subject matters.

Tacking into account that competencies are complex constructs that capacitate for decision making and performance, both expressed as specific behaviors, they can only be assessed by expert evaluators, ideally, in standardized conditions.

It has been said that at present, the main shortcomings lay in the tools available for assess-
Presidente de la Fundación Educación Médica.

E-mail aoriolb@gmail.com 
de capacidades que se expresan en la toma de decisiones y en el desempeño. Se trata de conductas que requieren a menudo, para ser evaluadas, de su observación por expertos evaluadores en condiciones idealmente estandardizadas.

Algunos autores han apuntado como la mayor dificultad actual la insuficiencia de los métodos de medida existentes [1], al considerarlos incapaces de cumplir con los requisitos exigibles: validez, fiabilidad, impacto educativo, coste y aceptabilidad [2]. Sin embargo, dichos autores identifican instrumentos que demuestran poseer no tan sólo validez general, sino también capacidad discriminatoria. También admiten que los 'portafolios' permiten documentar la actuación clínica basada en la evidencia y que la minievaluación clínica (mini-CEX) se muestra psicométricamente como un instrumento evaluador de las habilidades clínicas muy potente, al igual que los pacientes simulados estandarizados o la evaluación basada en la observación de entrevistas registradas en vídeo. Las dificultades para evaluar el profesionalismo pueden, a su vez, superarse mediante el 'feedback múltiple', originado por múltiples observadores y en entornos múltiples [3].

Otros autores, sin embargo, afirman que la mayor dificultad en la evaluación de las competencias no es tanto la falta de instrumentos de medida pertinentes como su uso inadecuado [4]. Las evaluaciones basadas en la observación del desempeño en el lugar de trabajo exigen disponer de evaluadores expertos tanto en la observación de las conductas de los evaluados como en la capacidad para emitir juicios sintéticos sobre lo observado [5], puesto que se han detectado deficiencias significativas de los evaluadores en su capacidad de observar directamente y en la evaluación realizada de lo observado [6]. Un buen instrumento en manos de un educador no experto no produce una evaluación de calidad [4].

Es posible desarrollar la capacidad evaluadora sobre la base de una formación y una práctica suficientes [7]. Resulta necesario, pues, formar a los evaluadores para poder desarrollar una educación orientada a las competencias, aunque aquí no acaban los problemas que plantea Bolonia. Falta, además, la comprensión de las distintas conductas esperables a lo largo de las diversas fases formativas para poder conocer en qué hay que concentrarse durante la observación ing competencies [1]. The existing ones fall short in fulfilling the required criteria (validity, reliability, educational impact, cost and acceptability) [2]. Nevertheless the same authors identify some measurement tools showing not only general validity but also discriminatory capacity, admitting that 'portfolios' allow to document evidence based clinical performance while mini-clinical-evaluations (mini-CEX), standardized-simulated-patients as well as video recorded clinical interviews are psychometrically very potent tools to assess clinical skills. The present difficulties to evaluate professionalism can be overcome through multiple feedback from multiple observers in multiple environments [3].

Nevertheless, Green \& Holmboe [4] maintain that the main limitation in competencies' assessment lays not so much in the shortage of adequate measurement tools but in the inappropriate use of those available. The assessment based on performance observation requires expert observers not only on the performances to be assessed but also in emitting synthetic judgments about what is observed [5], since significant shortcomings on both facets have been reported [6]. A good instrument in the hands of a non expert evaluator does not produce a quality assessment [4].

It is possible to develop the evaluation capabilities of educators with training and sufficient practice [7]. There is a need to train evaluators in order to be able to develop competency-basededucation as required by the Bologna process. But this is not the only problem to overcome since there is also an insufficient understanding of the performance dimensions expected along the different phases of the educational progress in order to know what to look for during the observations. 'An explicit set of expectations that would link the ideals of the general competencies to the realities of measurement' are necessary, according to Lurie et al [1].

The challenge posed by Bologna will not be successfully confronted if the Medical Schools do not equip themselves with interdepartmental units equipped with expertise in the educational and evaluation processes, contributing to the development of the educational capabilities of the academic staff, and contributing to bridge the departmental barriers. Being unable to measure what it is aimed at makes impossible to know how far out of target you are and how well Bologna's requirements have been attended. 
evaluativa. Es necesario disponer, como afirman Lurie et al [1], de 'las expectativas explicitadas de forma que sea posible relacionar las conductas deseables con las que ocurren en realidad.

El reto que supone Bolonia no podrá superarse con éxito si las facultades de medicina no se dotan de unidades interdepartamentales expertas en los procesos educativos y evaluativos, si no se desarrollan las capacidades de los docentes y si no se superan las barreras departamentales. Sin poder medir lo que se pretende alcanzar no será posible establecer si lo que se está haciendo logra los resultados esperados y, en consecuencia, no será posible saber si se cumple adecuadamente con los imperativos de Bolonia.

\section{Bibliografía / References}

1. Lurie SJ, Mooney CJ, Lyness JM. Measurement of the general competencies of the Accreditation Council for
Graduate Medical Education: a systematic review. Acad Med 2009; 84: 301-9.

2. Van der Vleuten CPM. The assessment of professional competence: developments, research and practical implications. Adv Health Sci Educ Theory Pract 1996; 1: 41-67.

3. Lockyer J, Clyman SG. Multisource feedback. In Holmboe ES, Hawkins RE, eds. Practical guide to the evaluation of clinical competence. Philadelphia: Mosby-Elsevier; 2008.

4. Green MI, Holmboe ES. The ACGME toolbox: half empty or half full? Acad Med 2010; 85: 787-90.

5. Norcini J, Burch V. Workplace-based assessment as an educational tool. AMEE Guide 31. Med Teach 2007; 29: 855-71.

6. Holmboe ES. Faculty and the observation of trainees' clinical skills: problems and opportunities. Acad Med 2004; 79: 16-22.

7. Holmboe ES, Hawkins RE, Huot SJ. Effects of training in directs observation of medical residents' clinical competence: a randomized trial. Ann Intern Med 2004; 140 : 874-81. 